\title{
Heavy Metal Concentrations and Risk Assessment of Sediments and Surface Water of the Gan River, China
}

\author{
Zhang Hua ${ }^{1,2}$, Jiang Yinghui ${ }^{2}$, Yang Tao ${ }^{1,2}$, Wang Min², \\ Shi Guangxun ${ }^{2}$, Ding Mingjun ${ }^{1,2, *}$ \\ ${ }^{1}$ Key Lab of Poyang Lake Wetland and Watershed Research, Ministry of Education (Jiangxi Normal University), \\ Jiangxi Nanchang, 330022, China \\ ${ }^{2}$ School of Geography and Environment, Jiangxi Normal University, No. 99, Ziyang Road, \\ Jiangxi Nanchang 330022, China
}

Received: 15 January 2016

Accepted: 7 March 2016

\begin{abstract}
To investigate the contamination levels of heavy metals, surface water and sediment samples were collected from 21 sites along the Gan River. The heavy metal concentrations ( $\mathrm{V}, \mathrm{Co}, \mathrm{Cr}, \mathrm{Ni}, \mathrm{Cu}, \mathrm{Zn}, \mathrm{Cd}$, and $\mathrm{Pb}$ ) were determined using inductively coupled plasma spectrometry (ICP-MS). The results demonstrated that the status of the surface water and sediments as a whole were relatively clean with regard to heavy metals (except for $\mathrm{Cd}$ ) compared to water quality standards and sediment quality guidelines. The two heavy metal sources of the surface water and sediments were identified separately using factor analysis (FA). High levels of metals were found in the sediment in the upstream and downstream due to frequent mining and industrial activities, whereas concentrations of heavy metal in the surface water from two sources were abundant in the upstream and midstream - likely related to mining activities and sediment suspension. As indicated by enrichment factor (EF) and potential ecological risk index (PERI), $\mathrm{Zn}, \mathrm{Pb}$, and $\mathrm{Cd}$ were the most anthropogenically enriched metals, while sediments in the upstream and downstream had high potential ecological risk. Local people, including adults and children who ingested water from the Gan River, showed little potential non-carcinogenic risk, as the hazard index (HI) scores were less than 1. Compared with those in other rivers in the world, heavy metal enrichments in surface water and sediments were of moderate levels.
\end{abstract}

Keywords: Gan River, heavy metals, surface water, sediments, risk assessment

\section{Introduction}

Anthropogenic activities have seriously affected the biogeochemical cycles of trace metals and have caused

*e-mail: zhalxx@163.com severe metal pollution in the environment, especially in aquatic ecosystems [1, 2]. Metals trapped in aquatic ecosystems have an effect on the environment and can even threaten human health through the food chain due to their abundance, environmental toxicity, persistence, and bioaccumulation [3-5]. One of the major sources of heavy metals to aquatic ecosystems is the increasing industrial 
or municipal effluent accompanying rapid urbanization and industrialization [6-7]. Acid mine drainage (AMD) released from mining and smelting processes are also significant sources of heavy metals in rivers [8]. In addition, pesticides and herbicides that are widely used in agriculture in developing countries may contain amounts of arsenic (As) and heavy metals that are easily transferred into rivers via agricultural runoff [2]. Once released into riverine systems, heavy metals from these sources may prevail in the water and easily accumulate in sediments [9]. The sediment is the main sink of exogenous pollutants. It is calculated that approximately $30-98 \%$ of the total metal load is in sediment-associated forms [10]. The sediment, serving as an ecological sink, can release metals back into the surface water due to environmental changes, such as in the $\mathrm{pH}$, conductivity, temperature, salinity, and so on. [11]. Such processes enhance the availability of heavy metals in aquatic ecosystems and can cause toxic effects on organisms [12]. Therefore, surface water and sediment in rivers are frequently used as indicators to monitor longterm metal enrichment and assess specific levels of heavy metal pollution [2].

In recent decades, many researchers developed different methods to evaluate heavy metal contamination in aquatic ecosystems. With regard to sediment, geochemical normalization and pollution indices were applied in risk assessment; i.e., contamination factor (CF) [13], sediment quality guidelines (SQGs) [14-15], geoaccumulation index $\left(\mathrm{I}_{\mathrm{Geo}}\right)$ [14-16], modified degree of contamination $\left(\mathrm{mC}_{\mathrm{d}}\right)$ [17], pollution load index (PLI) $[13,18]$, metal pollution index (MPI) [19], enrichment factor (EF) [14, 20-21], and potential ecological risk index (PERI) [15, 2122]. Although reviewing literature revealed that applying those methods on metals assessment was a controversial issue, geochemical normalization with conservative elements had been effectively used for evaluating the pollution degree of metal pollutants and identifying their anthropogenic and natural sources. Compared with sediment, relatively few methods have been applied in evaluating water quality. The heavy metal pollution index (HPI) was always used for evaluating drinking water quality [23], while the hazard index (HI) and excess cancer incidence (ELCR) were applied for human health risk assessment associated with the ingestion and dermal absorption of metals through water [2]. The latter method under a residential scenario was frequently used for evaluating heavy metals in water [2, 24-25].

In China, a great deal of research has focused on heavy metals enrichment in riverine systems since 2000 [26]. Unfortunately, few research studies have focused on assessing the levels of heavy metal contaminants in the Gan River, with only a few investigations reporting data on a certain metal or river section [27-29]. The Gan River, one of the main tributaries of Poyang Lake and similar to other rivers in China, is the only surface water source for local drinking water and is suffering from frequent anthropogenic impacts due to the pressure of severe mining plus ore dressing and smelting activities upstream; the metal-associated industry downstream; and densely inhabited areas in the whole basin. It has great significance to understand the heavy metal pollution status in the surface water and sediment in the Gan.

The purpose of this study is to characterize the pollution status of the Gan by analyzing the concentrations of heavy metals in the surface water and sediment. A particular study on the source and geographical variations of heavy metals was also conducted. Ultimately, the potential ecological risk for aquatic organisms and health risks associated with metals for the local inhabitants are provided.

\section{Material and Methods}

\section{Study Area}

The Gan River $\left(116^{\circ} 22^{\prime}-116^{\circ} 01^{\prime} \mathrm{E}, 25^{\circ} 57^{\prime}-29^{\circ} 11^{\prime} \mathrm{N}\right)$ is located in Jiangxi Province in southeast China. It is the largest river in Poyang Lake basin, the seventh largest river in the Yangtze River basin, and drains into Poyang Lake after a course of approximately $823 \mathrm{~km}$. It has a drainage basin of $82,809 \mathrm{~km}^{2}$, constituting more than $50 \%$ of Jiangxi Province and supporting more than 19 million inhabitants. It is the primary water source for the city along the river and is also a repository of domestic sewage, industrial wastewater, and mine drainage. Maximum flows occur from May to June, whereas minimum flows occur from January to February. The region has a subtropical humid monsoonal climate and the average annual precipitation is $1,580.8 \mathrm{~mm}$ [30]. The upstream area includes many non-ferrous mines, rare earth mines, and metal-associated industries [31]. The downstream area mainly includes some metal-associated industries such as the lead-acid battery enterprise. The cities of Ganzhou, Ji'an, and Nanchang are located upstream, midstream, and downstream, respectively, and are the three major settlements on the banks of the river that directly discharge industrial influents and domestic wastewater into the river. All of the above factors seriously threaten the water quality and health of local inhabitants. It is noteworthy that there is a major dam in operation between Ganzhou and Ji'an on the Gan River that allows for electric power generation, navigation, irrigation, and aquaculture.

\section{Sample Collection}

Surface water and sediment samples were collected from 21 typical sites along the Gan River (Fig. 1) in November 2013 after the end of the rainy season. In each site, three water replicates $(250 \mathrm{ml})$ were collected at a depth of approximately $10 \mathrm{~cm}$ using previously acidwashed polyethylene containers, which were subsequently well mixed. These mixed samples were immediately filtered through pre-washed $0.45-\mu \mathrm{m}$ nitrocellulose filters acidified to $\mathrm{pH}<2$ with suprapure nitric acid in situ. The upper 0-10 cm of sediment (approx. $500 \mathrm{~g}$ ) was collected at the same point as the water samples using a VanVeen grab sampler, repeated three times, and stored in polyethylene bags. Eventually, 21 water samples and 63 sediment 


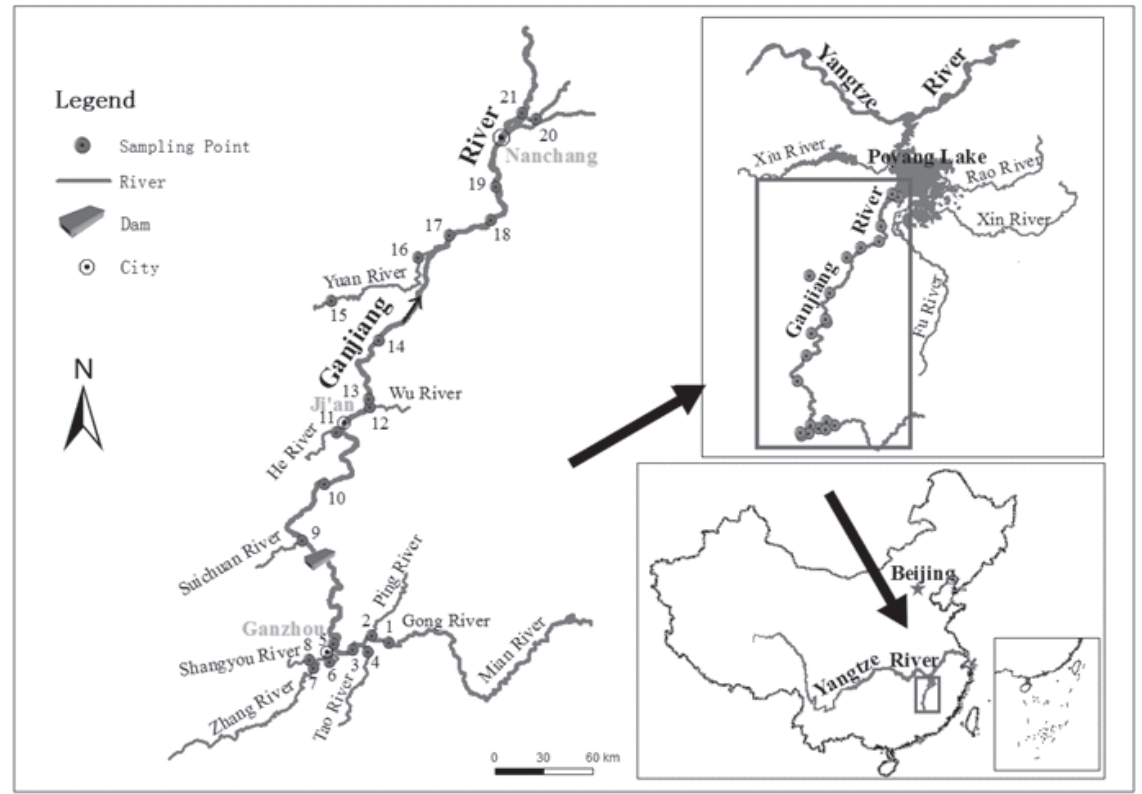

Fig. 1. Sampling sites along the Gan River.

samples were collected for laboratory analysis. To avoid contamination, the polyethylene containers and bags had been previously cleaned with a solution of $30 \%$ suprapure nitric acid for 24 hours to remove any interfering metals and subsequently were rinsed with Milli-Q water.

\section{Sample Preparation and Analytical Procedures}

The water and sediment samples were taken to the laboratory. Once at the laboratory, each water sample was stored at $4^{\circ} \mathrm{C}$ until further analysis. The sediment samples were air-dried, then passed through a 2-mm nylon sieve to remove large particles, and subsequently transferred to an oven to dry at $50^{\circ} \mathrm{C}$ until a constant weight was reached. Then these samples were ground and passed through a 100 -mesh sieve prior to analysis.

The method of extracting the total metal concentrations in sediment was based on Zhang [32]. In brief, a sample portion of dry sample (20-30 mg) was weighed and dissolved into $15 \mathrm{~mL}$ Teflon bombs. $1 \mathrm{~mL}$ of $\mathrm{HNO}_{3}+1 \mathrm{~mL}$ $\mathrm{HF}$ was added to the samples and they were evaporated to almost dryness at $150^{\circ} \mathrm{C}$. Subsequently, the residue was dissolved in a $1 \mathrm{ml} \mathrm{HNO}_{3}+1 \mathrm{ml} \mathrm{HF}$ sample, which was placed in a sealed stainless steel pot and heated in an electric oven to $190^{\circ} \mathrm{C}$ for more than $24 \mathrm{~h}$. Then the sample was put on a hot plate and evaporated to almost dryness at $150^{\circ} \mathrm{C}$. The residue was dissolved in $1 \mathrm{~mL} \mathrm{HNO}_{3}$ and evaporated to almost dryness at $150^{\circ} \mathrm{C}$, repeated twice. The final residue was re-digested by adding $2 \mathrm{ml} \mathrm{HNO}_{3}$ and $3 \mathrm{ml}$ Milli-Q water, which was placed in sealed bombs that were then placed in an oven at $150^{\circ} \mathrm{C}$ for more than $30 \mathrm{~h}$. Clear solution was yielded after this procedure and diluted for test. The total concentrations of the following eight metals were determined in all of the samples of water and sediment: canadium (V), chromium $(\mathrm{Cr})$, cobalt
(Co), nickel (Ni), copper ( $\mathrm{Cu}$ ), zinc $(\mathrm{Zn})$, cadmium $(\mathrm{Cd})$, and lead $(\mathrm{Pb})$. The heavy metal concentrations were measured by inductively coupled plasma spectrometry (ICP-MS). For sediment analysis, the quality assurance and quality control (QA/QC) procedures were conducted by using standard reference materials: GSD-2a and GSD3a (geochemical standard sediment). The accuracy of the results was controlled by using blank samples as control samples and by digesting duplicate samples. Recoveries varied but all fell within the range of $90-105 \%$, and the relative standard deviation (RSD) was within 5\%. With respect to surface water, quality control and method accuracy were triplicate checked by using a standard reference material (SRM, AccuStandard, Inc., USA), and the limit of detection (LOD) was $0.018 \mu \mathrm{g} / \mathrm{L}$ for $\mathrm{V}$, $0.019 \mu \mathrm{g} / \mathrm{L}$ for $\mathrm{Cr}, 0.007 \mu \mathrm{g} / \mathrm{L}$ for $\mathrm{Co}, 0.435 \mu \mathrm{g} / \mathrm{L}$ for $\mathrm{Ni}$, $0.143 \mu \mathrm{g} / \mathrm{L}$ for $\mathrm{Cu}, 0.042 \mu \mathrm{g} / \mathrm{L}$ for $\mathrm{Zn}, 0.004 \mu \mathrm{g} / \mathrm{L}$ for $\mathrm{Cd}$, and $0.003 \mu \mathrm{g} / \mathrm{L}$ for $\mathrm{Pb}$.

\section{Statistical Analysis}

To explore the metal sources and assess the status of the heavy metal contamination in river sediments, the enrichment factor (EF) was calculated using the following formula [33]:

$$
\mathrm{EF}_{\mathrm{n}}=\left[\mathrm{N}_{\mathrm{s}} / \mathrm{E}_{\mathrm{s}}\right] /\left[\mathrm{N}_{\mathrm{r}} / \mathrm{E}_{\mathrm{r}}\right]
$$

...where $\mathrm{EF}_{\mathrm{n}}$ is the enrichment factor for the metal $\mathrm{N} ; \mathrm{N}_{\mathrm{s}}$ is the metal concentration in the river sediment; $\mathrm{E}_{\mathrm{s}}$ is the reference metal concentration in the river sediment used for normalization; $\mathrm{N}_{\mathrm{r}}$ is the metal concentration in the crust; and $\mathrm{E}_{\mathrm{r}}$ is the concentration of the reference metal used in the crust for normalization. Generally, elements such as $\mathrm{Al}, \mathrm{Fe}$, and Si were employed as the reference metal [3435]. Based on Sutherland [36], five pollution levels were 
proposed as follows: $\mathrm{EF}<2$ indicates depletion to minimal enrichment, $2 \leq \mathrm{EF}<5$ represents moderate enrichment, $5 \leq \mathrm{EF}<20$ is significant enrichment, $20 \leq \mathrm{EF}<40$ is strong enrichment, and $\mathrm{EF} \geq 40$ indicates extreme enrichment.

To assess the degree of the comprehensive contamination of heavy metals in the sediments at a specific site, the potential ecological risk (PER) index was calculated by the following formula [35]:

$$
\begin{gathered}
\mathrm{E}_{\mathrm{r}}^{\mathrm{i}}=\mathrm{T}_{\mathrm{r}}^{\mathrm{i}} \times \mathrm{C}_{\mathrm{f}}^{\mathrm{i}}=\mathrm{T}_{\mathrm{r}}^{\mathrm{i}} \times\left(\mathrm{C}_{\mathrm{i}} / \mathrm{C}_{\mathrm{n}}\right) \\
\mathrm{RI}=\sum_{i=1}^{n} E_{r}^{i}
\end{gathered}
$$

...where RI is the comprehensive PER index, which is the sum of $\mathrm{E}_{\mathrm{r}}^{\mathrm{i}}$; $\mathrm{E}_{\mathrm{r}}^{\mathrm{i}}$ is the PER index of an individual metal; $\mathrm{C}_{\mathrm{f}}^{\mathrm{i}}$ is the single metal pollution factor (a ratio between the metal concentration in sediments and a reference value for the metal); and $\mathrm{T}_{\mathrm{r}}^{\mathrm{i}}$ is the biological toxic factor of an individual metal, which was defined as $\mathrm{Zn}=1$, $\mathrm{V}=\mathrm{Cr}=2, \mathrm{Co}=\mathrm{Ni}=\mathrm{Cu}=\mathrm{Pb}=5$, and $\mathrm{Cd}=30$ [3738]. The soil background values of Jiangxi Province were applied due to there being no available date referring to sediments in the Gan River [39]. Four pollution categories were made based on RI according to Tang et al. [35]: low $(\mathrm{RI}<150)$, moderate $(150 \leq \mathrm{RI}<300)$, high $(300 \leq \mathrm{RI}<600)$, and very high pollution ( $\mathrm{EF} \geq 600)$.

Heavy metals enter into the human body mainly through three pathways, including direct ingestion, inhalation through the mouth and nose, and dermal absorption through skin exposure $[24,40]$. With respect to metals in water, two main exposure pathways should be considered (such as ingestion and dermal absorption). In turn, a formula from the U.S. Environmental Protection Agency [41] was used for adults and children, separately. The exposure dose through ingestion (Eing) and dermal absorption (Ederm) were calculated as the following expressions:

$$
\begin{gathered}
\text { Eing }=\frac{C_{w} \times I R \times E F \times E D}{B W \times A T} \\
\text { Ederm }=\frac{C_{w} \times S A \times K_{p} \times E T \times E F \times E D \times C F}{B W \times A T}
\end{gathered}
$$

The values, descriptions, and sources of parameters in the above formulas are summarized in Table S1.

The human health risk was quantified by noncarcinogenic risk and carcinogenic risk. The hazard quotient (HQ), calculated as the ratio between the environmental exposure dose and the corresponding reference dose (RfD), was used for reflecting potential non-carcinogenic risks. Values of $\mathrm{HQ}>1$ are considered non-carcinogenic effects. In turn, the hazard index (HI), defined as the total potential non-carcinogenic effects posed by each exposure pathway, is the sum of the HQs from all applicable pathways. Similarly, if the HI exceeds
1 , there might be concern for an adverse effect on human health [41].

Data were statistically analyzed using the statistical software package PASW 17.0 (SPSS Inc., Chicago, USA). Shapiroe-Wilk's normality test was used for checking the normality. Factor analysis (FA) was used to identify overlying factors that analyze the interaction and the relationship between the different variables [24]. In FA, an orthogonal varimax rotation was used to rotate the axes for maximizing the variation among the variables. and factors with eigenvalues greater than 1 were extracted [42]. To ensure the appropriate application of FA, we performed the Kaiser-Mayer-Olkin (KMO) test and Bartlett's test of sphericity [43]. Reduction of variables is accepted when the KMO values are $>0.5$ and $p<0.05$ [44].

\section{Results and Discussion}

\section{Descriptive Statistics of Metal Levels in Water and Sediments}

The descriptive statistics of temperature, $\mathrm{pH}$ values, conductivity, and heavy metal levels in surface water and sediment are summarized in Table 1. To reflect the concentrations of heavy metals, on average, in water and sediment, different means (arithmetic mean, geometric mean, and median) were adopted due to different heavy metal concentrations following different distribution patterns [45]. Almost all of the heavy metal concentrations showed a normal distribution except the $\mathrm{Zn}$ and $\mathrm{Cd}$ concentrations in water, which behaved log-normally. $\mathrm{Zn}$ was the most abundant metal in river water, whereas $\mathrm{Cd}$ was the least. The mean concentrations of dissolved heavy metals, in increasing order, were $\mathrm{Cd}(0.185 \mu \mathrm{g} / \mathrm{kg})$, Co $(0.37 \mu \mathrm{g} / \mathrm{kg}), \mathrm{V}(0.94 \mu \mathrm{g} / \mathrm{kg}), \mathrm{Cr}(1.75 \mu \mathrm{g} / \mathrm{kg}), \mathrm{Ni}$ $(2.49 \mu \mathrm{g} / \mathrm{kg}), \mathrm{Pb}(3.07 \mu \mathrm{g} / \mathrm{kg}), \mathrm{Cu}(4.04 \mu \mathrm{g} / \mathrm{kg})$, and $\mathrm{Zn}$ $(10.59 \mu \mathrm{g} / \mathrm{kg})$. With respect to the metals in sediment, the most and least abundant metals were similar to those in water (Table 1). The percentage of CVs of $\mathrm{Zn}$ in surface water and $\mathrm{Cd}$ in surface water and sediment were clearly higher than that of other heavy metals in environmental media. The concentrations of these variables displayed great variability, which is most likely related to human activities [32].

Data on heavy metal levels in surface water were compared with Quality Standards for Surface Water, which was issued by the Chinese Ministry of Environmental Protection (CMEP). The Quality Standards for Surface Water (GB3838-2002) stipulates that surface water, including rivers, lakes, canals, channels, and reservoirs, are classified into five classes according to environmental function and protection goals [46]. Based on this classification, the Gan River is a watercourse categorized as grade I, the waters of which are suitable for a nature reserve (Table 1). Compared to drinking water guidelines by the World Health Organization [47], CMH [48], and the U.S. EPA [49], none of the metals showed concentrations higher than the level for drinking water. 
Table 1. Concentrations of heavy metals in sediment from the Gan River.

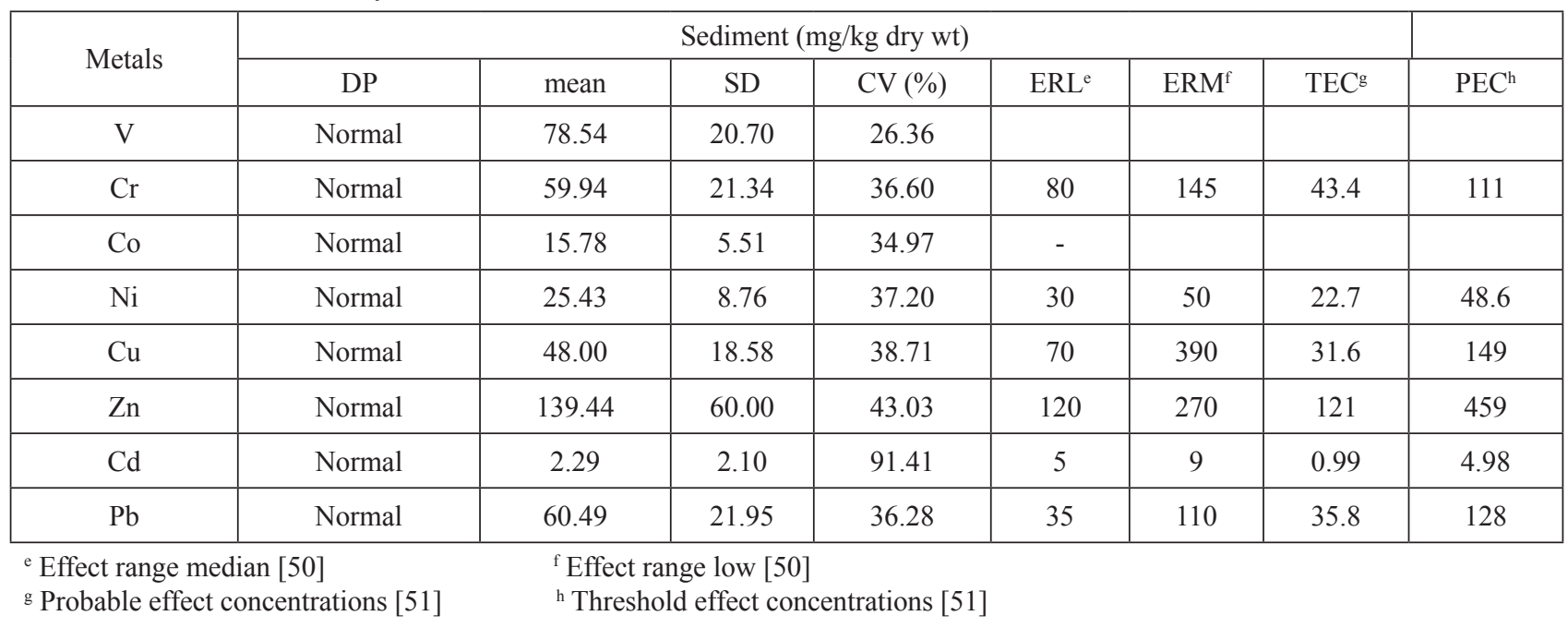

Due to a lack of sediment guideline values in the study area, a comparison with existing sediment quality guidelines (SQGs) was performed by taking the effect range-low (ERL), the effect range-medium (ERM), the consensus-based threshold effect concentration (TEC), and the consensus-based probable effect concentration (PEC) into account [50-51]. The mean concentrations of $\mathrm{Zn}$ and $\mathrm{Pb}$ were higher than the effect range-low (ERL) and lower than the effect range-medium (ERM), which represents a range in which biological effects occur occasionally [50]. The TEC (PEC) represents the chemical concentrations below (above) which adverse effects on sediment-dwelling organisms are not (are) expected to occur [51]. The mean concentrations of $\mathrm{Cr}, \mathrm{Ni}, \mathrm{Cu}, \mathrm{Zn}$, $\mathrm{Cd}$, and $\mathrm{Pb}$ were higher than the TEC but lower than the PEC. Levels of $\mathrm{Cd}$ in some sites were higher than the ERM and PEC (Table 1). The results indicate that Gan River sediment is relatively minimally polluted, except by $\mathrm{Cd}$ in some sites, which likely resulted in adverse effects on aquatic life and requires great attention.

\section{Source and Geographical Variations of Heavy} Metals in Surface Water and Sediment

Metals in the environment can be geogenic and also originate from anthropogenic inputs [52]. To determine the interrelationship of metals in surface water and sediment, factor analysis (FA) was applied on the relationship among metals in surface water and sediment. The KMO measurements are 0.719 and $0.711(p<0.001)$ for sediment and surface water, respectively, which are both higher than the recommended KMO value of 0.5 [44], indicating that the application of FA is appropriate for heavy metals. Finally, two factors with eigenvalues $>1$, extracted from both the sediment and surface water, accounted for $82 \%$ and $70 \%$ of the total variances, respectively. The rotated component matrix of the factor loadings of the eight elements is shown in Table 2.

Many previous studies used FA to identify the sources of metal pollution due to the understandable recognition that original variables are mutually significant $[32,53]$. Factor loading with values $>0.75,0.75-0.50$, and $0.50-0.30$ were classified as strong, moderate, and weak, respectively [54]. In the sediment, a total of two factors (F1 and F2) were extracted. The first factor (F1), accounted for $47.37 \%$ of the total variance and showed a strong positive correlation to $\mathrm{Co}, \mathrm{Cu}, \mathrm{Zn}, \mathrm{Cd}$, and $\mathrm{Pb}$ and a moderate positive correlation to Ni (Table 2). Tailings and wastewater from tungsten ore dressing plants upstream of the Gan River have been a major source of $\mathrm{Cd}$ pollution since 1960 [55]. Lead-acid battery enterprises in the downstream region possibly contributed the most to $\mathrm{Pb}$ pollution. Therefore, it was speculated that these metals in the first factor appeared to be primarily associated with anthropogenic inputs. Another factor (F2) explained $34.76 \%$ of the total variance and had strong positive loadings on $\mathrm{V}, \mathrm{Cr}$, and $\mathrm{Ni}$ and weak positive loadings on $\mathrm{Co}$ and $\mathrm{Zn}$. These metals were likely to be of lithogenic origin due to relatively lower levels and percentage of

Table 2. Factor loading for selected heavy metals in the sediment and water (Rotate component matrix).

\begin{tabular}{|c|c|c|c|c|}
\hline \multirow{2}{*}{ Metals } & \multicolumn{2}{|c|}{ Sediment } & \multicolumn{2}{c|}{ Water } \\
\cline { 2 - 5 } & F1 & F2 & PC1 & PC2 \\
\hline $\mathrm{V}$ & 0.179 & $\mathbf{0 . 9 3 1}$ & $\mathbf{0 . 9 0 1}$ & 0.205 \\
\hline $\mathrm{Cr}$ & 0.043 & $\mathbf{0 . 9 6 6}$ & $\mathbf{0 . 7 9 1}$ & -0.235 \\
\hline $\mathrm{Co}$ & $\mathbf{0 . 7 7 0}$ & 0.424 & $\mathbf{0 . 6 1 9}$ & 0.261 \\
\hline $\mathrm{Ni}$ & 0.528 & $\mathbf{0 . 7 6 2}$ & -0.155 & $\mathbf{0 . 9 2 4}$ \\
\hline $\mathrm{Cu}$ & $\mathbf{0 . 8 0 9}$ & 0.158 & $\mathbf{0 . 8 9 9}$ & 0.099 \\
\hline $\mathrm{Zn}$ & $\mathbf{0 . 8 8 3}$ & 0.376 & $\mathbf{0 . 6 2 4}$ & 0.289 \\
\hline $\mathrm{Cd}$ & $\mathbf{0 . 8 0 4}$ & -0.066 & 0.482 & $\mathbf{0 . 7 7 3}$ \\
\hline $\mathrm{Pb}$ & $\mathbf{0 . 8 9 6}$ & 0.226 & $\mathbf{0 . 8 2 2}$ & -0.049 \\
\hline Eigenvalue & 3.790 & 2.781 & 3.949 & 1.713 \\
\hline \% of variance & 47.369 & 34.761 & 49.367 & 21.418 \\
\hline
\end{tabular}


CV (Table 1). In the surface water, two major principal components were identified. The first PC (PC1) explained $49.37 \%$ of the total variance and showed a strong positive correlation to $\mathrm{V}, \mathrm{Cr}, \mathrm{Co}, \mathrm{Cu}, \mathrm{Zn}$, and $\mathrm{Pb}$, and a moderate positive correlation to $\mathrm{Cd}$. The second PC (PC2) accounted for $21.42 \%$ of the total variance and was only strongly positively correlated with $\mathrm{Ni}$ and $\mathrm{Cd}$. The metals in each principle component identified in water and those in each factor extracted from the sediment were different, probably due to the interaction between the long history of sedimentation and frequent dredging in the Gan [5657]. This result was also found in a previous study [34].

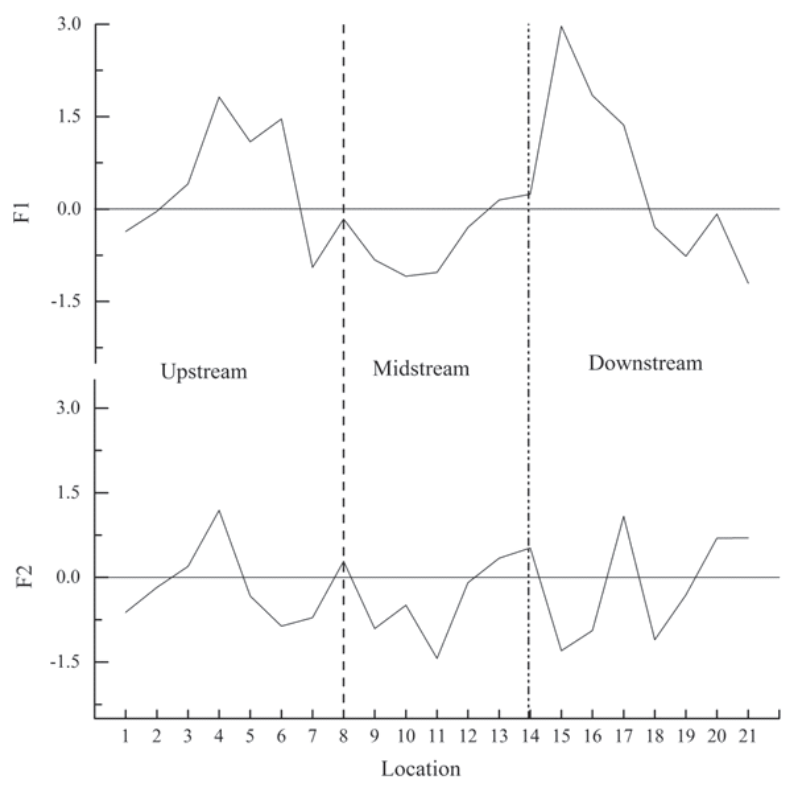

Fig. 2. Factor scores of metals in sediments along the Gan River.

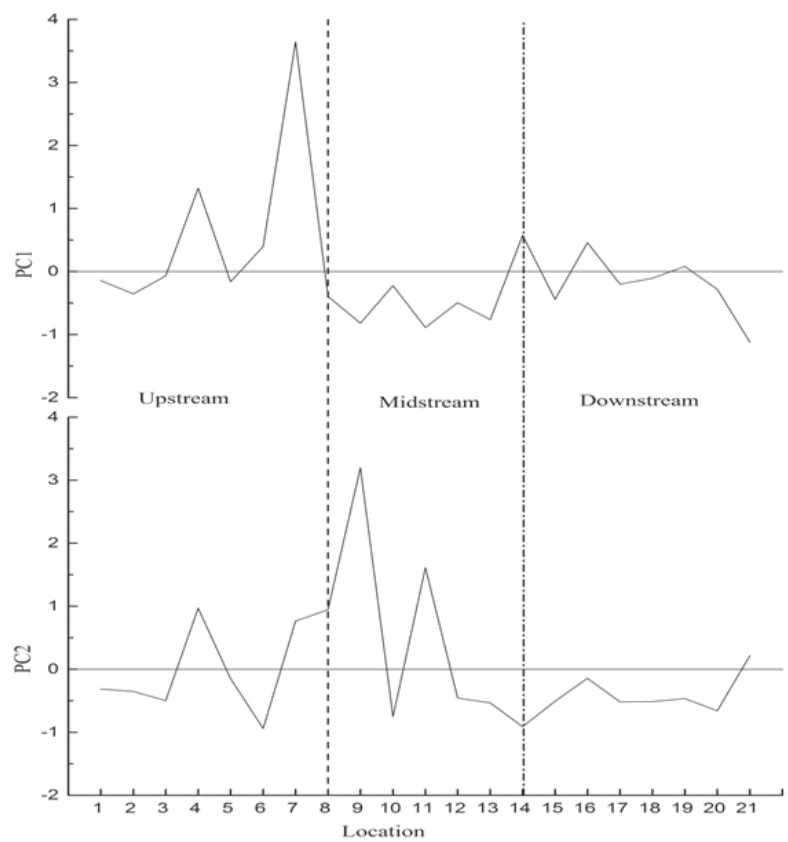

Fig. 3. PC scores of metals in the surface water along the Gan River.
The presentation of the factor scores according to sampling sites was applied to further verify the interpretation of factors and exhibit the geographical variations of heavy metals (Figs 2-3). In the sediment, the high scores of the first factor (F1) occurred upstream and downstream, where many metal mines (tungsten and rare earth mines), ore dressing plants, and lead-acid battery enterprises are distributed [28, 58]. The contribution of the second factor (F2) was most profound in the upstream area, which is likely due to the high background. With respect to the surface water, $\mathrm{PC} 1$ was positively correlated with $\mathrm{V}, \mathrm{Cr}, \mathrm{Co}, \mathrm{Cu}, \mathrm{Zn}$, and $\mathrm{Pb}$, and had high scores in the upstream area due to high concentrations of these metals in the sediment, which were probably released to the surface water through sediment suspension [11]. The contribution of PC2 was positively correlated with $\mathrm{Cd}$ and $\mathrm{Ni}$ and showed that the contribution of the second source was most profound at sites 4, 7, 8, 9, and 11. With the exception of sites 9 and 11, which are located downstream of the Wan'an reservoir, these sites were identified as nonferrous metal processing zones that might discharge abundant acid mine drainage (AMD) into the river water [28]. Although a great quantity of heavy metal enriched into the suspended matter would deposit into the sediment through the retention effects of the reservoirs, sites 9 and 11 obtained high scores (Fig. 3). This was probably due to the effect of tungsten mining activities on these two sites in which the pollution originated in the catchment area of the Suichuang and Helu tributaries (Fig. 1). The decreased velocity of the flow in the main stream led to a great quantity of heavy metal settlement onto the sediment, which resulted in the surface water of other sites in the main stream containing small quantities of heavy metals [58].

\section{Heavy Metal Contamination in Sediments}

Generally, elements such as Al, Fe, and Si were used as reference metal $\mathrm{E}$ in formula (1) to assess the heavy metal contamination levels [34-35]. In this study, V was used as

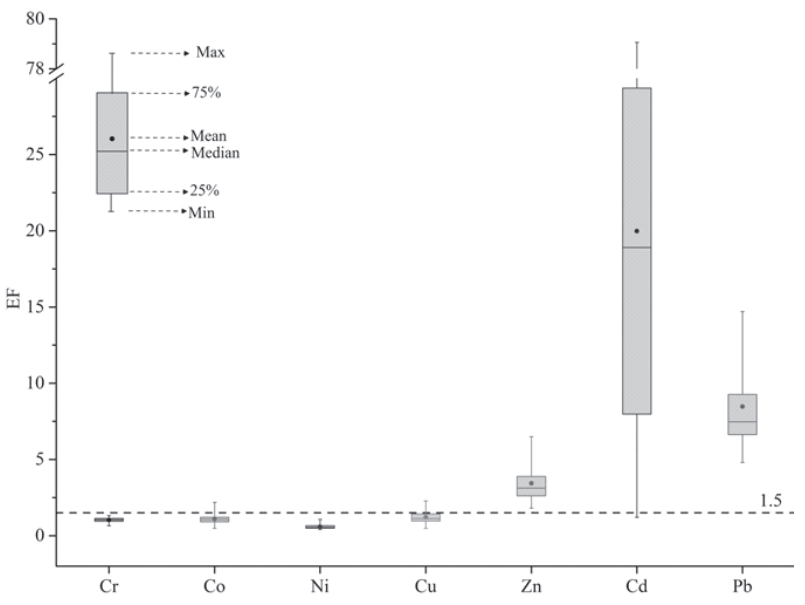

Fig. 4. EF values for metals in Gan River sediments. 


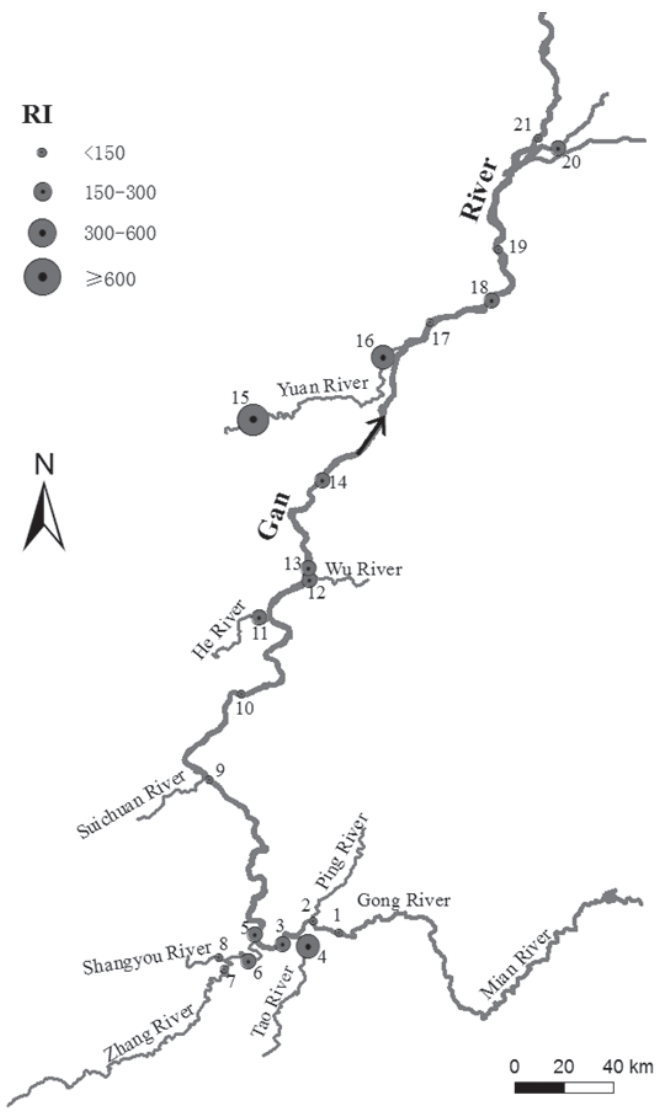

Fig. 5. PER indexes of heavy metals in Gan River sediments.

reference metal E because of its low \% CV (Table 1) and significantly different statistical relationship with metals of anthropogenic origin (Table 2). The concentration of Er was $135 \mathrm{mg} / \mathrm{kg}$ based on the $\mathrm{V}$ average crustal abundance data and Es is derived from the $\mathrm{V}$ sediment concentrations of different sampling sites [59].

The EFs of each metal were calculated and are presented in Fig. 4. The mean EF values of all of the studied heavy metals indicate contamination in the Gan River sediments. The mean EF was highest for
Cd (19.98), indicating significant pollution and the highest level of anthropogenic pollution of this metal, followed by $\mathrm{Pb}$ (8.46), $\mathrm{Zn}$ (3.43), $\mathrm{Cu}$ (1.21), Co (1.10), $\mathrm{Cr}$ (1.02), and $\mathrm{Ni}$ (0.58). EF was also widely used to separate metals associated with anthropogenic activities from those from natural sources [60]. Generally, an EF value of approximately 1 indicates that a given metal originated entirely from natural weathering processes or crustal material, whereas values of $>1.5$ suggest that anthropogenic activities may be an important source [61-62]. The average $\mathrm{EF}$ values for $\mathrm{Cd}, \mathrm{Pb}$, and $\mathrm{Zn}$, and a portion of EF values of $\mathrm{Co}$ and $\mathrm{Cu}$ exceeded 1.5, indicating that a portion of these heavy metals originated from anthropogenic activities. On the contrary, all of the $\mathrm{EF}$ values of $\mathrm{Ni}$ and $\mathrm{Cr}$ were lower than 1.5, suggesting that these two metals originated from natural weathering processes or crustal material. This result is consistent with form factor analysis (Table 3). Some researchers have demonstrated a significant correlation between the EF values of metals and their corresponding non-residual fractions, which were an indication of anthropogenic inputs and caused negative biological effects on aquatic organisms $[60,63]$. Therefore, the government needs to pay more attention to the enrichment of $\mathrm{Cd}, \mathrm{Pb}$, and $\mathrm{Zn}$ in the sediments of the Gan River.

Comprehensive potential ecological risk (RI), which was applied to show the sensitivity of the biological community to integrated pollutants and assess the risk posed by pollution [64], is displayed in Fig. 5. The RIs of heavy metals ranged from 42.71 to 651.94 , indicating a scope from low pollution to very high pollution. Cd accounted for approximately $69 \%$ of RIs on average. The high RIs occurred at site 4 (upstream) and sites 15 and 16 (downstream), which are located in the tributary. The distribution map of RI is consistent with Fig. 2 and was useful in identifying sites that need the most attention.

\section{Risk Assessment on Human Health}

Concentrations of metals in water can be used to assess human exposure through oral ingestion and bathing [2].

Table 3. Reference dose and hazard quotient for elements of the Gan River, China.

\begin{tabular}{|c|c|c|c|c|c|c|c|c|}
\hline \multirow{2}{*}{ Metal } & \multirow{2}{*}{$\begin{array}{c}\mathrm{RfD}_{\text {dermal }} \\
(\mu \mathrm{g} / \mathrm{kg} / \text { day })\end{array}$} & \multirow{2}{*}{$\begin{array}{l}\mathrm{RfD}_{\text {ingenstion }} \\
(\mu \mathrm{g} / \mathrm{kg} / \text { day })\end{array}$} & \multicolumn{2}{|c|}{$\mathrm{HQ}_{\text {ingenstion }}$} & \multicolumn{2}{|c|}{$\mathrm{HQ}_{\text {dermal }}$} & \multicolumn{2}{|c|}{$\mathrm{HI}=\sum \mathrm{HQs}$} \\
\hline & & & Adult & Child & Adult & Child & Adult & Child \\
\hline $\mathrm{V}$ & 0.13 & 5 & $6.88 \mathrm{E}-03$ & $1.71 \mathrm{E}-02$ & $1.95 \mathrm{E}-05$ & $3.28 \mathrm{E}-05$ & $6.90 \mathrm{E}-03$ & $1.71 \mathrm{E}-02$ \\
\hline $\mathrm{Cr}$ & 0.075 & 3 & $2.13 \mathrm{E}-02$ & $5.29 \mathrm{E}-02$ & $1.26 \mathrm{E}-04$ & $2.12 \mathrm{E}-04$ & $2.14 \mathrm{E}-02$ & $5.31 \mathrm{E}-02$ \\
\hline $\mathrm{Co}$ & 0.06 & 0.3 & 4.47E-02 & $1.11 \mathrm{E}-01$ & $1.65 \mathrm{E}-05$ & $2.77 \mathrm{E}-05$ & 4.47E-02 & $1.11 \mathrm{E}-01$ \\
\hline $\mathrm{Ni}$ & 0.8 & 20 & $4.55 \mathrm{E}-03$ & $1.13 \mathrm{E}-02$ & $1.68 \mathrm{E}-06$ & $2.82 \mathrm{E}-06$ & $4.55 \mathrm{E}-03$ & $1.13 \mathrm{E}-02$ \\
\hline $\mathrm{Cu}$ & 8 & 40 & $3.70 \mathrm{E}-03$ & $9.18 \mathrm{E}-03$ & $2.86 \mathrm{E}-05$ & $2.30 \mathrm{E}-06$ & $3.73 \mathrm{E}-03$ & $9.18 \mathrm{E}-03$ \\
\hline $\mathrm{Zn}$ & 60 & 300 & $3.12 \mathrm{E}-03$ & 7.73E-03 & $6.88 \mathrm{E}-07$ & $1.16 \mathrm{E}-06$ & $3.12 \mathrm{E}-03$ & $7.73 \mathrm{E}-03$ \\
\hline $\mathrm{Cd}$ & 0.025 & 0.5 & $2.99 \mathrm{E}-02$ & $7.42 \mathrm{E}-02$ & 4.40E- 05 & 7.42E-05 & 2.99E-02 & 7.42E-02 \\
\hline $\mathrm{Pb}$ & 0.42 & 1.4 & $8.02 \mathrm{E}-02$ & $1.99 \mathrm{E}-01$ & 7.87E-08 & $1.33 \mathrm{E}-07$ & $8.02 \mathrm{E}-02$ & $1.99 \mathrm{E}-01$ \\
\hline
\end{tabular}

$\mathrm{Rfd}$ (reference dose) of metals from risk-based concentration table [65] expect $\mathrm{Pb}$ from WHO [47]. 
The Gan is the only surface water for local drinking and living. Therefore, it is necessary to assess local human exposure from using this water. Some parameters were chosen according to the specific situations of population exposure to assess risk from ingestion and dermal pathways (Table S1). In this study we examined the ingestion rate of water (IR) and the exposed skin surface area (SA) of inhabitants with similar living habits. The winter climate was considered because the sampling occurred in winter (Table S1).

Table 3 presents the HQ, HI, and risk values for oral consumption and dermal absorption of water in winter relating to adults and children. The $\mathrm{HQ}_{\text {ingestion }}$ (hazard quotient of ingestion exposure) of all metals for adults were smaller than 1, indicating that these metals in water pose a minimal hazard to local inhabitants. Similar to adults, $\mathrm{HQ}_{\text {ingestion }}$ of metals for children was also below
1 , and the highest value was 0.20 for $\mathrm{Pb}$. Compared to $\mathrm{HQ}_{\text {ingestion, }} \mathrm{HQ}_{\text {dermal }}$ (hazard quotient of dermal absorption), which was several orders of magnitude smaller, could be considered to be negligible, with values ranging between $7.87 \times 10^{-8}$ and $2.12 \times 10^{-4}$ (Table 3 ). This result suggests that the concentrations of these metals may pose little or no potential health threat through dermal adsorption. The highest $\mathrm{HI}$ of metals for adults and children was $\mathrm{Pb}$, followed by $\mathrm{Co}, \mathrm{Cd}, \mathrm{Cr}, \mathrm{V}, \mathrm{Ni}, \mathrm{Cu}$, and $\mathrm{Zn}$ - all of which were $<1$. Similar to previous studies, the exposure risks of children from oral consumption and dermal absorption were higher than those of the adults in this study [2, 24].

Although some uncertainties such as body weight $\left(B_{w}\right)$, ingestion rate of water (IR), and exposed skin surface area (SA) were localized, other uncertainties remain for the methods adopted in this study, which have been emphasized by other studies [24, 40, 66-67].

Table 4 Comparative levels of heavy metals in the surface water and sediments in the Gan River with other rivers in the world.

\begin{tabular}{|c|c|c|c|c|c|c|c|c|c|c|}
\hline & Site & $\mathrm{V}$ & $\mathrm{Cr}$ & $\mathrm{Co}$ & $\mathrm{Ni}$ & $\mathrm{Cu}$ & $\mathrm{Zn}$ & $\mathrm{Cd}$ & $\mathrm{Pb}$ & References \\
\hline \multicolumn{11}{|c|}{ a) surface water $(\mu \mathrm{g} / \mathrm{L})$} \\
\hline \multirow{13}{*}{$\begin{array}{l}\text { Poyang } \\
\text { lake Basin }\end{array}$} & Gan River & 0.94 & 1.75 & 0.37 & 2.49 & 4.04 & 10.59 & 0.608 & 3.07 & This study \\
\hline & Rao River, China & & 3.56 & & & 116.81 & 21.01 & & 1.33 & {$[68]$} \\
\hline & Fu River, China & & & & 8.53 & 6.77 & 4.59 & 0.110 & 2.08 & {$[69]$} \\
\hline & Xiushui River, China & & & & 0.81 & 3.87 & 3.85 & 0.130 & 2.49 & [69] \\
\hline & Xin River, China & & & & 2.74 & 5.30 & 10.28 & 2.210 & 0.49 & [69] \\
\hline & Poyang Lake & & 3.38 & & & 4.18 & 11.19 & & 4.06 & {$[68]$} \\
\hline & Yangtze River, China & & 6.34 & 0.51 & 1.55 & 2.43 & 9.56 & 0.200 & 0.77 & {$[70]$} \\
\hline & Upper Han River. China & 140.01 & 10.51 & ND & 0.14 & 0.66 & & 0.570 & 26.12 & {$[24]$} \\
\hline & Comti River, India & & 63.33 & & 44.17 & 21.50 & 66.50 & 23.50 & 17.67 & {$[71]$} \\
\hline & Beneu River, Nigeria & & 381.90 & & & 56.00 & 78.70 & & 207.00 & {$[72]$} \\
\hline & Tigris River, Turkey & & 25.41 & & 24.54 & 17.10 & 12.01 & 0.044 & 2.82 & {$[43]$} \\
\hline & $\begin{array}{c}\text { Sacramento River, Unite } \\
\text { State }\end{array}$ & 2.55 & 0.26 & $<0.016$ & 0.74 & 0.81 & 1.50 & $<0.018$ & 0.010 & {$[73]$} \\
\hline & Pardo River, Brazil & 1.31 & ND & & 1.65 & 1.77 & 11.60 & ND & 3.27 & {$[2]$} \\
\hline \multicolumn{11}{|c|}{ b) sediment (mg/kg dry wt) } \\
\hline \multirow{9}{*}{$\begin{array}{c}\text { Poyang } \\
\text { Lake } \\
\text { Basin }\end{array}$} & Gan River & 78.54 & 59.94 & 15.78 & 25.43 & 48.00 & 139.44 & 2.29 & 60.49 & This study \\
\hline & Le'an River* & & & & & 56.43 & 251.00 & 3.26 & 61.99 & {$[74]$} \\
\hline & Poyang Lake & & 28.05 & & & 61.53 & 194.11 & 1.54 & 48.17 & {$[75]$} \\
\hline & Yangtze River, China & & 89.54 & 18.53 & 37.40 & 82.00 & 174 & 2.46 & 60.00 & {$[76]$} \\
\hline & Yuan River, China & & 85.44 & & & 114.90 & 78.46 & 2.54 & 75.87 & {$[77]$} \\
\hline & Comti River, India & & 16.19 & & 23.92 & 23.23 & 76.34 & 4.98 & 46.20 & {$[71]$} \\
\hline & Pardo River, Brazil & 61.31 & 23.59 & & 5.43 & 14.43 & 29.44 & 0.03 & 6.87 & {$[2]$} \\
\hline & Morava River, Czech & 32.44 & 50.99 & 9.94 & 35.74 & 31.34 & 135.36 & 0.55 & 23.63 & {$[78]$} \\
\hline & Saale River, Germany & 66.5 & 386 & 42.2 & 124 & 83.2 & 813 & 3.17 & 82.9 & {$[79]$} \\
\hline
\end{tabular}

$\mathrm{ND}=$ no detectable

* Le'an River is the tributary of Rao River, which was affected by enormous mining activities. 
These uncertainties include the permeability coefficient $(\mathrm{Kp})$ and a varied exposure condition because different receptors could not be localized. In addition, the RfD from the U.S. EPA and WHO might not be suitable for local inhabitants in the study area. As a consequence, exposure risk assessment needs to be more localized for a more detailed risk level assessment in the Gan basin. In addition, some metals, such as $\mathrm{Tl}$ and As, were identified as two priority pollutants in water causing non-carcinogenic and carcinogenic concerns [2, 24]. Therefore, a more comprehensive and accurate risk assessment that includes a greater number of metals, sampling sites, and seasons is required for future study.

\section{Comparison of Metals in Sediment with Other Studies in the World}

The Gan River along with four other rivers, including the Fu, Xin, Rao, and Xiushui, flows into Poyang Lake the largest freshwater lake that lies on the southern bank of the Yangtze River (Fig. 1). A comparison of heavy metal concentrations in the surface water and sediment observed for the Gan with those of the other rivers in the Yangtze basin and the world is shown in Table 4.

The level of metals in the surface water in the Gan was moderate compared with the other four rivers in the same basin, except for $\mathrm{Pb}$, and was comparable to that of Poyang Lake but higher than that of the Yangtze, with the exceptions of $\mathrm{Cr}$ and $\mathrm{Co}$. It is noteworthy that the level of metals in the Gan is substantially lower than that reported in the Rao, which has been affected by large-scale mining activities [26]. Compared to the Han, the main tributary of the Yangtze, the levels of some metals in the Gan were higher, including $\mathrm{Co}, \mathrm{Ni}, \mathrm{Cu}$, and $\mathrm{Cd}$, while some were lower, including $\mathrm{V}, \mathrm{Cr}$, and $\mathrm{Pb}$. In addition, the levels of metals in the Gan were found to be higher compared to studies reported in the United States, similar to studies in Brazil, and lower compared to studies in India, Nigeria, and Turkey (Table 4).

With respect to metals in the sediment, the levels in the Gan were lower than those in the Le'an River and the Yangtze. The concentrations of $\mathrm{Cu}$ and $\mathrm{Zn}$ in Poyang Lake were greater than those in the Gan, whereas the levels of $\mathrm{Cr}, \mathrm{Cd}$, and $\mathrm{Pb}$ in the former were lower - indicating that $\mathrm{Cu}$ and $\mathrm{Zn}$ in the Gan were likely not the sole source for Poyang Lake. Although similarly influenced by mining activities, the levels of metals in the Yuan were much higher than those in our study, except for $\mathrm{Zn}$ [77]. Compared to other rivers in the world, the concentrations of metals in the sediment of the Gan were of a moderate level. In general, our results were comparable to unpolluted rivers.

\section{Conclusion}

The current levels of metals in surface water sampled in the Gan were generally in accordance to the quality standards established by the Chinese authority, WHO, and the U.S. EPA. The sediments in the Gan were relatively cleaner, except for $\mathrm{Cd}$, compared to existing SQGs. High metal levels in the sediment associated with anthropogenic sources mainly occurred in upstream and downstream regions due to frequent mining and industrial activities. The concentrations of metals in the surface water that were high upstream and midstream likely related to mining activities and sediment suspension according to FA. As indicated by $\mathrm{EF}, \mathrm{Zn}, \mathrm{Pb}$, and $\mathrm{Cd}$ were the most anthropogenically enriched metals and made the largest contribution to contamination of Gan sediments. Sediments of sites 4 (upstream) and 15 and 16 (downstream) had the highest potential ecological risk (RI) and require greater attention. Human risk in winter was assessed in inhabitants exposed to heavy metals. The results suggest that the intake of water from the Gan was not currently a pathway of concern for local people, as the hazard index (HI) for adults and children was $<1$. Heavy metal concentrations in surface water and sediments were of moderate levels compared with those in other rivers in the world. As these results are only the outcome of the first screening, the current conclusions should be regarded only as preliminary and require further investigation.

\section{Acknowledgements}

This study was supported by the Opening Fund of the Key Laboratory of Poyang Lake Wetland and Watershed Research (Jiangxi Normal University, Ministry of Education) (grant No. PK2013002), the Collaborative Innovation Center for Major Ecological Security Issues of Jiangxi Province and Monitoring Implementation (grant No. JXS-EW-00), and the National Natural Science Foundation of China (grant Nos. 41401587 and 41201033).

\section{References}

1. KRISHNA A.K., SATYANARAYANAN M., GOVIL P.K. Assessment of heavy metal pollution in water using multivariate statistical techniques in an industrial area: a case study from Patancheru, Medak District, Andhra Pradesh, India. J. Hazard. Mater. 167 (1), 366, 2009.

2. ALVES R.I.S., SAMPAIO C.F., NADAL M., SCHUHMACHER M., DOMINGO J.L., SEGURAMUÑOZ S.I. Metal concentrations in surface water and sediments from Pardo River, Brazil: Human health risks. Environ. Res. 133, 149, 2014.

3. SIN S.N., CHUA H., LO W., NG L.M. Assessment of heavy metal cations in sediments of Shing Mun River, Hong Kong. Environ. Int. 26 (5), 297, 2001.

4. POURANG N., RICHARDSON C.A., CHENERY S.R.N., NASROLLAHZEDEH H. Assessment of trace elements in the shell layers and soft tissues of the pearl oyster Pinctada radiata using multivariate analyses: a potential proxy for temporal and spatial variations of trace elements. Environ. Monit. Assess. 186 (4), 2465, 2014.

5. LAVOIE R.A., JARDINE T.D., CHUMCHAL M.M., KIDD K.A., CAMPBELL L.M. Biomagnification of mercury 
in aquatic food webs: a worldwide meta-analysis. Environ. Sci. Technol. 47 (23), 13385, 2013.

6. LIN C.Y., HE M.C., LIU X.T., GUO W., LIU S.Q. Contamination and ecological risk assessment of toxic trace elements in the Xi River, an urban river of Shenyang city, China. Environ. Monit. Assess. 185 (5), 4321, 2013.

7. KRISHNA A.K., MOHAN K.R. Risk assessment of heavy metals and their source distribution in waters of a contaminated industrial site. Environ. Sci. Pollut. Res. 21 (5), 3653, 2014.

8. GÓMEZ-ÁLVAREZ A., VALENZUELA-GARCÍA J.L., MEZA-FIGUEROA D., de la O-VILLANUEVA M., RAMIREZ-HERNÁNDEZ J., TAPIA-ALMENDARIZ J., SEGURA-PÉREZ E. Impact of mining activities on sediments in a semi-arid environment: San Pedro River, Sonora, Mexico. Appl. Geochem. 26 (12), 2101, 2011

9. JAIN C.K., GUPTA H., CHAKRAPANI G.J. Enrichment and fractionation of heavy metals in bed sediments of River Narmada, India. Environ. Monit. Assess. 141 (1-3), 35, 2008.

10. GIBBS R.J. Mechanisms of trace metal transport in rivers. Science 180 (4081), 71, 1973.

11. SUPERVILLE P.J., PRYGIEL E., MAGNIER A., LESVEN L., GAO Y., BAEYENS W., OUDDANE B., DUMOULIN D., BILLON G. Daily variations of $\mathrm{Zn}$ and $\mathrm{Pb}$ concentrations in the Deûle River in relation to the resuspension of heavily polluted sediments. Sci. Total Environ. 470, 600, 2014.

12. NIU H.Y., DENG W.J., WU Q.H., CHEN X.G. Potential toxic risk of heavy metals from sediment of the Pearl River in South China. J. Environ. Sci. 21 (8), 1053, 2009.

13. FUJITA M., IDE Y., SATO D., KENCH P.S., KUWAHARA Y., YOKOKI H., KAYANNE H. Heavy metal contamination of coastal lagoon sediments: Fongafale Islet, Funafuti Atoll, Tuvalu. Chemosphere 95, 628, 2014.

14. DAVUTLUOGLU O.I., SECJIN G., ERSU C.B., YILMAZ T., SARI B. Assessment of metal pollution in water and surface sediments of the Seyhan River, Turkey, using different indexes. Clean-Soil Air Water 39 (2), 185, 2011.

15. FU J., HU X., TAO X.C., YU H.X., ZAND X.W. Risk and toxicity assessments of heavy metals in sediments and fishes from the Yangtze River and Taihu Lake, China. Chemosphere 93 (9), 1887, 2013.

16. MA X.L., ZUO H., TIAN M.J., ZHANG L.Y., MENG J., ZHOU X.N., MIN N., CHANG X.Y., LIU Y. Assessment of heavy metals contamination in sediments from three adjacent regions of the Yellow River using metal chemical fractions and multivariate analysis techniques. Chemosphere. 144, 264, 2016.

17. JAMSHIDI-ZANJANI A., SAEEDI M. Metal pollution assessment and multivariate analysis in sediment of Anzali international wetland. Environ. Earth Sci. 70 (4), 1791 2013.

18. WAZNE M., KORFALI S. Spatial and temporal assessment of metal pollution in the sediments of the Qaraoun reservoir, Lebanon. Environ. Sci. Pollut. Res. Doi: 10.1007/s11356015-6022-1, 2016.

19. HORTELLANI M.A., SARKIS J.E.S., MENEZES L.C.B, BAZANTE-YAMAGUISHI, R., PEREIRA A.S.A., GARCIA P.F.G., MARUYAMA L.S., CASTRO P.M.G. Assessment of metal concentration in the billings reservoir sediments, São Paulo State, Southeastern Brazil. J. Brazil. Chem. Soc. 24 (1), 58, 2013.

20. WANG X.C., FENG H., MA H.Q. Assessment of metal contamination in surface sediments of Jiaozhou Bay, Qingdao, China. Clean-Soil Air Water 35 (1), 62, 2007.

21. ZANG Z.Y., LI J.Y., MAMAT Z., YE Q.F. Sources identification and pollution evaluation of heavy metals in the surface sediments of Bortala River, Northwest China. Ecotox. Environ. Safe. 126, 94, 2016.

22. ZHANG L.W., SHAO H.B. Heavy Metal Pollution in Sediments from Aquatic Ecosystems in China. Clean - Soil Air Water 41 (9), 878, 2013.

23. GIRI S., SINGH A.K. Assessment of surface water quality using heavy metal pollution index in Subarnarekha River, India. Water. Qual. Expos. Hea. 5 (4), 173, 2014.

24. LI S.Y., ZHANG Q.F. Risk assessment and seasonal variations of dissolved trace elements and heavy metals in the Upper Han River, China. J. Hazard. Mater. 181 (1), 1051, 2010.

25. ZENG X.X., LIU Y.G., YAO S.H., ZENG G.M., TAN X.F., HU X.J., HU X., HUANG L., LI F. Spatial distribution, health risk assessment and statistical source identification of the trace elements in surface water from the Xiangjiang River, China. Environ. Sci. Pollut. R. 22 (12), 9400, 2015.

26. TAO L., LIU G.N., LIU X.H., ZHANG C., CHENG D.M., WANG A.J., LI R.P. Trace metal pollution in a Leran River tributary affected by non-ferrous metal mining activities in Jiangxi Province, China. Chem. Ecol. 30 (3), 233, 2014.

27. LIU X.Z., JIN J., YANG X.Y., SHU H.Y., HU L.N., LI Q.Y. Studies the distribution of perpendicularity pollution of $\mathrm{Cu}$ element of sediments in Wucheng section of Ganjiang River. Journal of Nanchang Hangkong University (Natural Science) 21 (3), 80, 2007 [In Chinese].

28. JI Y., ZHANG J., HUANG X., BAI C., CHEN X. Investigation and assessment of heavy metals in surface sediments of Ganjiang River, China. J. Environ. Biol. 35, 1173, 2014.

29. ZHANG B.J., ZHU M.M., WANG P., YUAN P., CHENG X.L., CAI H.P. Spatial and temporal distribution of dissolved cadmium in and water quality assessment of the water body of the Ganjiang River catchment. J. Ecol. Rural Environ. 30 (4), 495, 2014 [In Chinese].

30. JPHB (Jiangxi provincial hydrology bureau). Jiangxi drainage. Changjiang Press, Wuhan, 2007.

31. WU Y.L. The situation of heavy metal pollution prevention and control and its according strategies. Chem. Ind. Jiangxi 12, 131, 2012 [In Chinese].

32. ZHANG H., WANG Z.F., ZHANG Y.L., HU Z.J. The effects of the Qinghai-Tibet railway on heavy metals enrichment in soils. Sci. Total Environ. 439, 240, 2012.

33. ATIEMO S.M., OFOSU F.G., ABOH I.J.K., OPPON O.C. Levels and sources of heavy metal contamination in road dust in selected major highways of Accra, Ghana. X-ray Spectrum 41, (2), 105, 2012.

34. THUONG N.T., YONEDA M., IKEGAMI M., TAKAKURA M. Source discrimination of heavy metals in sediment and water of To Lich River in Hanoi City using multivariate statistical approaches. Environ. Monit. Assess. 185 (10), 8065, 2013

35. TANG W.Z., ZHAO Y., WANG C., SHAN B.Q., CUI J.G. Heavy metal contamination of overlying waters and bed sediments of Haihe Basin in China. Ecotox. Environ. Safe. 98, 317, 2013.

36. SUTHERLAND R.A. Bed sediment-associated trace metals in an urban stream, Oahu, Hawaii. Environ Geol 39 (6), 611, 2000.

37. HAKANSON L. An ecological risk index for aquatic pollution control. A sedimentological approach. Water Res. $14(8), 975,1980$

38. XU Z.Q., NI S.J., TUO X.G., ZHANG C.J. Calculation of heavy metals' toxicity coefficient in the evaluation of potential ecological risk index. Environ. Sci. Technol. 31 (2), 112, 2008 [In Chinese]. 
39. CNEMC (China National Environmental Monitoring Center). The backgrounds of soil environment in China. China Environmental Science Press, Beijing, 1990.

40. WU B., ZHAO D.Y., JIA H.Y., ZHANG Y., ZHANG X.X., CHENG S.P. Preliminary risk assessment of trace metal pollution in surface water from Yangtze River in Nanjing Section, China. B. Environ. Contam. Tox. 82 (4), 405, 2009.

41. USEPA. Risk Assessment Guidance for Superfund. Volume I: Human Health Evaluation Manual (Part E). EPA/540/R/99/005 OSWER 9285.7-02EP PB99-963312, 2004.

42. LU W.D. SPSS statistical analysis. 4th ed. Publishing House of Electronics Industry, Beijing, 2010.

43. VAROL M., GÖKOT B., BEKLEYEN A. Dissolved heavy metals in the Tigris River (Turkey): spatial and temporal variations. Environ. Sci. Pollut. Res. 20 (9), 6096, 2013.

44. MERKLE L.A., LAYNE C.S., BLOOMBERG J.J., ZHANG J.J. Using factor analysis to identify neuromuscular synergies during treadmill walking. J. Neurosci. Meth. 82 (2), 207, 1998.

45. CHEN M., MA L.Q., HOOGEWEG C.G., HARRIS W.G. Arsenic background concentrations in Florida, USA surface soils: determination and interpretation. Environ. Forensics 2 (2), 117, 2001.

46. CMEP (Ministry of Environmental Protection, PR China). Environmental quality standards for surface water (GB38382002). Beijing, 2002.

47. WHO. Guidelines for drinking water quality, 3rd edn. Incorporating first addendum. Recommendations, vol. I, WHO, Geneva, 2006.

48. CMH (Ministry of Health, PR China). Standards for Drinking Water Quality (GB5749-2006). Beijing, 2007.

49. USEPA. Edition of the drinking water standards and health advisories. Washington DC, 2006.

50. LONG E. R., MORGAN L. G. The potential for biological effects of sediments-sorbed contaminants tested in the National Status and Trends Program. Seattle: National Oceanic and Atmospheric Administration Technical Memorandum, USA, 1990.

51. MACDONALD D.D., INGERSOLL C.G., BERGER T.A. Development and evaluation of consensus-based sediment quality guidelines for freshwater ecosystems. Arch. Environ. Con. Tox. 39 (1), 20, 2000.

52. ZAHARESCU, D.G., HOODA P.S., SOLER A.P., FERNANDEZ J., BURGHELEA C.I. Trace metals and their source in the catchment of the high altitude Lake Respomuso, Central Pyrenees. Sci. Total Environ. 407 (11), 3546, 2009.

53. MICÓ C., RECATALÁ L., PERIS M., SÁNCHEZ J. Assessing heavy metal sources in agricultural soils of an European Mediterranean area by multivariate analysis. Chemosphere 65 (5), 863, 2006.

54. LIU C.W., LIN K.H., KUO Y.M. Application of factor analysis in the assessment of groundwater quality in a blackfoot disease area in Taiwan. Sci. Total Environ. 313 (1), 77, 2003.

55. CAI S.W., YUE L., Hu Z.N., ZHONG X.Z., YE Z.L. XU H.D., LIU Y.R., JI R.D., ZHANG W.H., ZHANG F.Y. Cadmium exposure and health effects among residents in an irrigation area with ore dressing wastewater. Sci. Total Environ. 90, 67, 1990.

56. MARTIN C.W. Heavy metal trends in floodplain sediments and valley fill, River Lahn, Germany. Catena 39 (1), 53, 2000.

57. ZHANG L.L., Tan Z.J., Li K. Impact of sand-dredging on river-bed of mid-lower reaches of Gan River. Hydropower New Energy 5, 63, 2010 [In Chinese].
58. ZHANG W.L., DU Y., ZHAI M.M., SHANG Q. Cadmium exposure and its health effects: A 19-year follow-up study of a polluted area in China. Sci. Total Environ. 470, 224, 2014.

59. TAYLOR S.R., MCLENNAN S.M. The geochemical evolution of the continental crust. Rev. Geophys. 33 (2), $241,1995$.

60. GAO X.L., CHEN C.T.A. Heavy metal pollution status in surface sediments of the coastal Bohai Bay. Water Res. 46 (6), 1901, 2012.

61. ZHANG J., LIU C.L. Riverine composition and estuarine geochemistry of particulate metals in China - weathering features, anthropogenic impact and chemical fluxes. Estuar. Coast. Shelf. S. 54 (6), 1051, 2002.

62. FENG H., HAN X.F., ZHANG W.G., YU L.Z. A preliminary study of heavy metal contamination in Yangtze River intertidal zone due to urbanization. Mar. Pollut. Bull. 49 (11), 910, 2004.

63. ISLAM M.S., AHMED M.K., RAKNUZZAMAN M., HABIBULLAH-AL-MAMUN M., ISLAM M.K. Heavy metal pollution in surface water and sediment: A preliminary assessment of an urban river in a developing country. Ecol. Indic. 48, 282, 2015.

64. SURESH G., SUTHARSAN P., RAMASAMY V., VENKATACHALAPATHY R. Assessment of spatial distribution and potential ecological risk of the heavy metals in relation to granulometric contents of Veeranam lake sediments, India. Ecotox. Environ. Safe. 84, 117, 2012.

65. USEPA. Risk-based concentration table. United state Environmental Protection Agency. Accessed March 16, 2015. http://www.epa.gov/reg3hwmd/risk/human/rbconcentration_table/Generic_Tables/index.htm, 2014.

66. WANG Z., LIU S.Q., CHEN X.M., LIN C.Y. Estimates of the exposed dermal surface area of Chinese in view of human health risk assessment. J. Saf. Environ. 8 (4), 152, 2008 [In Chinese].

67. YANG Y., YU Y.J., WEI W.W., LI D.L., YANG J. Health risk assessment of heavy metals in shallow groundwater in urban and suburban areas of Changzhou. Environ. Chem. 32 (2), 202, 2013 [In Chinese].

68. HU C.H., ZHOU P., HUANG P., DU J., ZHOU W.B. Behavior characteristics of dissolved heavy metals and health risks assessment from Poyang Lake basin, China. J. Agro-Environ. Sci. 31 (5), 1009, 2012 [In Chinese].

69. LI W.M., YANG Z.F., ZHOU L., TANG M., YUAN G.L., LIU C. Geochemical Characteristic and Fluxes of Heavy Metals in Water System of the Poyang Lake. Geoscience $\mathbf{2 8}$ (3), 512, 2014 [In Chinese].

70. YANG Z.F., XIA X.Q., WANG Y.P., JI J.F., WANG D.C., HOU Q.Y., YU T. Dissolved and particulate partitioning of trace elements and their spatial-temporal distribution in the Changjiang River. J. Geochem. Explor. 145, 114, 2014.

71. GUPTA S.K., CHABUKDHARA M., KUMAR P., SINGH J., BUX F. Evaluation of ecological risk of metal contamination in river Gomti, India: A biomonitoring approach. Ecotox. Environ. Safe. 110, 49, 2014.

72. ENEJI I.S., SHA'ATO R., ANNUNE P.A. An assessment of heavy metals loading in River Benue in the Makurdi Metropolitan Area in Central Nigeria. Environ. Monit. Assess. 184 (1), 201, 2012.

73. TAYLOR H.E., ANTWEILER R.C., ROTH D.A., ALPERS C.N., DILEANIS P. Selected trace elements in the Sacramento River, California: Occurrence and distribution. Arch. Environ. Con. Tox. 62 (4), 557, 2012

74. JIAN M.F., YOU H., NI C.Y. Characteristics of heavy metal contaminant status and migration in Rao River of Lake Poyang. J. Lake Sci. 18 (2), 127, 2006 [In Chinese]. 
75. HU C.H., LI M., XIA Y. The pollution characteristics and potential ecological risk assessment of heavy metals in the surface sediments of Poyang Lake. Journal of Jiangxi Normal University (Natural Science) 35 (4), 427, 2011 [In Chinese].

76. WANG L., WANG Y.P., XU C.Y., AN Z.Y. Pollution characteristics and ecological risk assessment of heavy metals in the surface sediments of the Yangtze River. Environ Sci 33 (8), 2509, 2012 [In Chinese].

77. CUI B., ZHU M.L., JIANG Y., JIANG Y.X., CAO H.B. Identification of the sources of metals and arsenic in river sediments by multivariate analysis and geochemical approaches. J. Soil. Sediment. 14 (8), 1546, 2014.

78. BEDNAROVA Z., KUTA J., KOHUT, L., MACHAT J., KLANOVA J., HOLOUBEK I., JARKOVSKY J., DUSEK L., HILSCHEROVA K. Spatial patterns and temporal changes of heavy metal distributions in river sediments in a region with multiple pollution sources. X-ray Spectrum. 13 (7), 1257, 2013

79. MÖLLER S., EINAX J.W. Metals in sediments - spatial investigation of Saale River applying chemometric tools. Microchem. J. 110, 233, 2013. 